\title{
UKRAINIAN SECOND-STAGE NONCONFORMISM: FEATURES OF DEVELOPMENT
}

Purpose of the study is to present the author's standpoint on the issue of inner resistance in the non-liberal Ukrainian art community. The research covers the period since the 1960s through 1980s, when the author was a student at the Kyiv State Art Institute, a researcher at the Museum of Folk Architecture and Life of the Ukrainian SSR, a senior researcher at the Ukrhudozprom (Ukrainian applied arts enterprise), and a member of the Union of Artists of Ukraine. Using the previously unpublished materials (his own diary, interviews with the participants in the process, memories of artists, workers and members of the National Union of Artists of Ukraine), the author suggests an interpretation of the problem of Ukrainian nonconformism with regard not only to the artistic, but also to the sociocultural component of the phenomenon. The methodology employed in the study includes new methods of studying nonconformism, built primarily on the author's own experience. In addition, the methods of art history studies and analysis, the structural-functional approach and the method of interviewing were used. The applied methodological approach broadened possible understanding of the long-hushed issue of artistic resistance to the official totalitarian doctrine. Scientific novelty of the results. The author intends to cover the problem basing on the impartial analysis of the studies of Ukrainian and foreign art historians and on the author's own experience as the participant of the art process of the time. The article for the first time presents author's personal theoretical approach to the important scientific problem, arising from a situation with no unanimous opinion and assessment of the artistic phenomenon. Conclusions. The revival of nonconformism as a cultural and artistic phenomenon meant enacting of modernist stylistics, embracing forbidden formalism and using postmodern trends within the cultural space of Soviet Ukraine. After the death of Stalin historical conditions changed, and the artistic circles reacted on temporary political "thaw" accordingly-that was a start of inevitable social changes resulting in new artistic phenomena and new artistic forms. As for the Ukrainian nonconformism, it should be noted that it never mimicred artistic life of the West of the studied period. As to the global context, it, undoubtedly, influenced the Ukrainian "phenomenon of dissent". The methodology of the avant-garde ideas, as well as its stylistics, were revived anew in the Ukrainian nonconformism of the 1960s through 1980s. The "second revival" of nonconformism in Ukraine was the transgression of the so-called "Executed Renaissance" of the 1920s and early 1930s.

Keywords: nonconformism, dissent, socialist realism, artist, art studies, culturology.

Роготченко Олексій Олексійович, доктор мистецтвознавства, старший науковий співробітник, головний науковий співробітник відділу теорії та історії культури Інституту проблем сучасного мистецтва Академії мистецтв України

Український нонконформізм другої фази: особливості розвитку

Мета статті полягає у оприлюдненні авторського бачення проблеми супротиву у невільному українському художньому соціумі. Основою дослідження $€$ 60-80-ті роки минулого століття - час коли автор був студентом Київського державного художнього інституту, науковим співробітником Музею народної архітектури та побуту УРСР, старшим науковим співробітником Укрхудожпрому (Українські художні промисли), членом Спілки художників України. Використовуючи раніше не публіковані матеріали (власний щоденник, інтерв'ю з учасниками процесу, спогади митців, працівників та членів НСХУ (Національної спілки художників України), автор пропонує прочитання проблеми українського нонконформізму, посилаючись не лише на мистецьку, але й на соціокультурну складову зазначеного явища. Методологія пропонованого дослідження полягає у застосовані автором нових методів вивчення нонконформізму, побудованих у першу чергу на власному досвіді. Також були залучені історикомистецтвознавчий метод та метод аналізу, структурно-функціональний підхід та метод інтерв'ювання у дослідженні поставленої проблеми. Застосований методологічний підхід розширив можливості правильного розуміння довго замовчуваної проблеми мистецького спротиву офріційній тоталітарній доктрині. Наукова новизна отриманих результатів полягає у висвітленню задекларованої теми шляхом неупередженого аналізу досліджень праць українських та іноземних мистецтвознавців та власного досвіду автора - учасника процесу, що досліджується. У статті вперше запропоноване власне теоретичне бачення важливої наукової проблеми, що витікає із ситуації, коли не існує єдиної думки і оцінки з приводу мистецького явища. Висновки. Відродження нонконформізму у якості культурно-мистецького явища означало відтворення стилістики модернізму, забороненого формалізму та застосування постмодерністських течій у культурному просторі Радянської України. Видозмінені історичні умови на тлі тимчасового «потепління» політичного клімату після смерті Й. Сталіна, спровокували відповідну реакцією мистецьких кіл на невідворотні соціальні зміни, що були викликані новими художніми явищами та новими мистецькими формами. Стосовно вітчизняного нонконформізму слід зазначити, що він ніколи не імітував мистецьке життя західного світу досліджуваного періоду. Що до світового контексту, то останній, безперечно, впливав на українське «явище незгоди». Методологія ідей авангарду, його мистецька стилістика знайшли своє нове відображення в українському нонконформізмі $1960-$ 1980-х років. «Друге відродження» нонконформізму України стало трансгресією «розстріляного відродження» 1920-х — початку 1930-х без застосування митцями жодних медикаментів.

Ключові слова: нонконформізм, незгода, соціалістичний реалізм, художник, мистецтвознавство, культурологія.

Роготченко Алексей Алексеевич, доктор искусствоведения, старший научный сотрудник, главный научный сотрудник отдела теории и истории культуры Института проблем современного искусства Академии искусств Украины

Украинский нонконформизм второй фазы: особенности развития

Цель статьи заключается в раскрытии авторского видения проблемы противодействия в несвободном украинском художественном социуме. Основой исследования становятся 60-80-е годы прошлого века - время, когда автор был студентом Киевского государственного художественного института, научным сотрудником Музея народной архитектуры и быта УССР, старшим научным сотрудником Укрхудожпрома (Украинские художественные промыслы), членом Союза художников Украины. Используя ранее не публиковавшиеся материалы (собственный дневник, интервью с участниками процесса, воспоминания художников, работников и членов НСХУ (Национального союза художников Украины), автор предлагает прочтение проблемы украинского нонконформизма, ссылаясь не только на искусствоведческую, но и на социокультурную составляющую указанного явления. Методология предлагаемого исследования заключается в применении автором новых методов изучения нонконформизма, 
построенных в первую очередь на собственном опыте. Также были привлечены историко-искусствоведческий метод и метод анализа, структурно-функциональный подход и метод интервьюирования в исследовании поставленной проблемы. Примененный методологический подход расширил возможности правильного понимания долго замалчиваемой проблемы художественного сопротивления офрициальной тоталитарной доктрине. Научная новизна полученных результатов, заключается в освещении задекларированной темы путем беспристрастного анализа исследований работ украинских и иностранных искусствоведов, а также собственного опыта автора - участника исследуемого процесса. В статье впервые предложено собственное теоретическое видение важной научной проблемы, которая вытекает из ситуации, когда не существует единого мнения и оценки по поводу художественного явления. Выводы. Возрождение нонконформизма в качестве культурно-художественного явления означало воспроизведение стилистики модернизма, запрещенного формализма и применения постмодернистских течений в культурном пространстве Советской Украины. Видоизмененные исторические условия на фоне временного «потепления» политического климата после смерти И. Сталина, спровоцировали ответную реакцию художественных кругов на неизбежные социальные изменения, вызванные новыми художественными явлениями и новыми художественными формами. Относительно отечественного нонконфрормизма следует отметить, что он никогда не имитировал художественную жизнь западного мира исследуемого периода. Что касается мирового контекста, то последний, безусловно, влиял на украинское «явление несогласия». Методология идей авангарда, его художественная стилистика нашли свое новое отражение в украинском нонконформизме 1960-1980-х годов. «Второе возрождение» нонконформизма Украины стало трансгрессией «расстрелянного возрождения» 1920-х - начала 1930-х без применения художниками никаких медикаментов.

Ключевые слова: нонконформизм, несогласие, социалистический реализм, художник, искусствоведение, культурология.

Present-day democratic society explores and studies a variety of artistic and cultural issues not researched in past historical periods. Currently the focus of attention switched, among others, on the theme of artistic resistance in totalitarian states. The literature and fine art of Soviet Ukraine since the 1930s through 1980 s is probably the least studied subject. This phenomenon has a logical explanation. The repressive apparatus of the state was so powerful, and the number of security service agents in the artistic environment was so massive that occasional acts of dissent by the artists had no affect on the overall historical process. The author proposes to distinguish two stages within the resistance movement of Ukrainian artists and writers. The first stage started during the extermination of free artistic groups in the early 1930s and lasted until the outbreak of World War II. The second phase took place since the end of the 1950 s and turned out to be more powerful than the first one. It may be assumed that the second stage ended during the late 1980s and early 1990s, thus becoming the basis for the third stage of the resistance. This massive transformation is rooted in collective rejection of the state-imposed artistic doctrine-socialist realism. Group and individual protests that started during the period still periodically occur up to this day. The proposed study outlines the events of the second stage of the resistance of the Ukrainian art community and reveals the author's vision of this problem.

The processes of confrontation between Ukrainian artists and the official doctrine are among the least studied issues of art and culture research as of today. Open and latent opposition to the totalitarian system has a logical term definition. Nonconformism could be specified as dissent and avertion by an individual to the ideological foundations of the ruling regime. Universally, culturology defines the artists' resistance as a different way of thinking, a revolt of a certain stratum of people, denial of state ideology and impossibility to exist within the proposed morality.

As for the history of the term "nonconformism" itself, it dates back to the period of the Reformation and to the first "dissenters" against the Church of England during the 16th and 17th centuries. The undermined authority of the traditional perception of rational academic and realistic doctrines during the last third of the 19th and early 20th century initiated the nonconformist artistic experiments in many fields of visual culture. This was the period of the first interest of sociology and philosophy in the theory of dissent and civil disobedience, which in turn led to the rapid formation of theoretical and terminological foundations of nonconformism. Nonconformism, or non-conformance, derives from from Latin "nonconformist", meaning discrepancy, non-uniformity, dissent. The term became particularly relevant for the Soviet Union of the 1960s and was used to dub individuals and artistic events that opposed the dominant culture and fine art. The 1960 s entered the history of culture as a period tolerant "towards the only true creative method called socialist realism." "...nonconformism in its essence is a local manifestation of alternative culture" [1, 235]. Resistance to the official art doctrine of the Ukrainian Soviet Socialist Republic became a popular theme of research papers during the last decades. Probably, the pendulum just swung in the opposite direction. In the past, Ukrainian culturologists, historians, art historians were afraid to write the truth about events, when the "proposed" method of socialist realism was an official directive. Moreover, its ideologists, in addition to the writing of laudatory essays, researches and publication, also spied on those critics and artists, who did not profess the official the propaganda. On the contrary, these days there is a desire and an opportunity for art historians to research artistic resistance.

However, the years when the real events were silenced, provoked the other distortion. The period of forced silence corrupted the accuracy of the events record, therefore today it is possible to come across an entire nonsense, and at times a total lie about events that in fact never happened. One can even get familiar with the "participants" of those non-existent events. Many artists who professed the profitable art of socialist realism, whose works were exhibited at state art exhibitions, who received thousands of state commisions, were later on attributed the dissent with the system by the critics, while this so-called "silent struggle" never actually happened to them. Only a very small circle of artists opposed the authorities. Yet a fewer number of artists lived in the so-called "inner emigration." To describe the artistic community of post-war time as a fully 
supportive of the official art would be an exaggeration. Yet, stating that a significant part of the artists was drawn to nonconformism would be exaggeration as well.

The author of the current paper and his family actively participated in the artistic life of the republic; such experience allows not only to draw a realistic outline of the events of 1950 s and 1960 but also to understand the underlying causes of behavior and actions of the creators and viewers of the art of the era. Reflecting on their behavior and actions without a preliminary explanation of some significant circumstances (not only of artistic, but also of socio-cultural, psychological, philosophical, and economic nature), would lead to bias in perception.

An important issue in the study of dissenters is the problem of embracing and professing the dominant method of the Soviet state-socialist realism. The vast majority of artists in the post-war period willingly embraced the proposed artistic method for several reasons. The first reason was not at all artistic, as many contemporary critics state, but economic one. It was difficult even to a mainstream artist to stray from the artistic method, where academic component remained dominant, and the theme was always a secondary issue. Photographically accurate academic depiction-be it a portrait, a genre painting, realistic landscape, sculpture or graphics - remained the only way for practically all plot lines. Only under one condition was it possible to sell one's work at a republican or all-Union exhibition or to receive a commision from an artistic foundation-the work had to be realistic. Non-realistic work would not make it to exhibition and, of course, would not be commissioned. It should be noted that the only source of income for the artist was official art exhibitions and official commisions from the artistic enterprises, magazines or publishing houses. Consequently, the artist who dared to oppose the existing system faced complete lack of earnings. Before the war (1941-1945) and in the first decades of the post-war period fear remained an important factor of artists' obedience, as well as of anybody living in USSR. The fear of getting into a concentration camp prompted people to be humble. Only since the late 1950s the public became less afraid of physical elimination. After the end of Joseph Stalin's cult of personality was officially proclaimed, the creative intelligentsia enjoyed a relative comfort. However, only to some extent, as a campaign against so-called cosmopolitanism unfolded at the turn of the 1950s. Many Jewish and Ukrainian artists and writers fell victims of the campaign.

Previously convicted writers, composers, artists and workers of theatre gradually returned from the concentration camps. That marked the start of the first manifestations of dissent with the official art doctrine. Therefore the other two components that contribute to understanding the artist's inner state come to light. That is, psychological and philosophical factors.

It should be emphasized that a number of Ukrainian researchers of culture, historians, art critics, depicting the hardships of the time, operated the real facts while building up their storyline. Mainly, they used the audio recording of the interviews with the participants of the events. Such studies were issued by Olesia Avarmenko, Glib Vysheslavskiy, Orest Holybets, Borys Lobanovskyi, Victor Sydorenko, Lesia Smyrna, Galyna Skliarenko, Oleksiy Tytarenko, Oleksiy Rohotchenko, Oleksandr Fedoruk. Foreign scholars also turned to the Ukrainian dissenting art: i.e. Matthew Bown, Igor Golomstock, Hans Gunther, Yevgeniy Dobrenko, Ekaterina Degot, Aleksandr Morozov, Vladimir Paperny, etc.

During the post-war era, the artworks of different genres follow this path of dissent with the Soviet apparatus. Not only writers and artists but also journalists, composers, folk artists, art critics, literary historians are to be mentioned. The present-day democratic society rejects the state pressure on the dissenters. This allows correct understanding and right evaluation of the past events. While studying the philosophy of the dissenters of the second-stage nonconformist, one should keep in mind, what exactly was rejected by the creative community that cast aside the state morale doctrine. The dissenters were opposed by the whole army of workers of the ideological apparatus, that is, culture departments at the regional and district party committees, special sections of the KGB, the Council of Ministers, Central Committee of the Communist Party, Central Committee of the Komsomol, Communist Party committees at the art unions, as well as the "conscious" members of the latter unions and their staff that informed curators about the dissenters affairs.

Ardent supporters of aestethic doctrine and morale of the state were assigned to their fellow artists who did not embrace socialist realism. The first ones mostly collaborated with KGB (State Security Committee) or were its agents and performed curatorial functions. The main lure were the open letters in support of one of the imprisoned dissidents. Upon signing this document, investigation of the artist's affairs started, and soon he could find himself behind bars. Ukrainian art researchers did not turn to nonconformism for a long time with the situation changing only after the Proclamation of Independence. Finally, there was a real opportunity to objectively investigate the movement of dissenters within not only cultural, but social context as well. Despite all the hardships of today's life, primarily the ongoing war, Ukraine remains a democratic state. Consequently, the values of the exterminated generations recur, the declassified facts and events are returned into circulation and, most importantly, the little-known or unknown names of the artists who were not afraid to express their position in relation to uncontested socialist morality and imposed method of socialist realism, come out of oblivion. "I will not say that I was starving at the turn of the 1960s. I had my daily bread. What was lacking is the sense of freedom and opportunities," tells Volodymyr Mykyta, an art critic and painter from Uzhgorod, in his interview [3]. These days the vast majority of creative students, 
answering the question on the history of Ukrainian art, would safely state that dissenters' art of the 1960s through the 1980s marked the beginning of free thinking. It also laid ground to the new reflection on the one of the most painful pages in the development of Ukrainian art by an art world.

In fact, there is still no single theory and vision among art historians. Probably this is a sign of a democratic society, or perhaps scientists may see and understand commonly known facts from the history of art in different ways. In any case, there is none one and only true solution and neither could it be. The author has his individual vision of the milestone moments in the development of Ukrainian dissenting art.

For instance, most of the Ukrainian schoolars date nonconformism as back as early 1960s. There is some ground for this statement. The famous Fence Exhibition of Stanislav Sychov and Valentin Khrushch, the young Odessa-based artists, was one of the first recorded events of Ukrainian underground. The exhibition took place in 1967, when young artists hung their works on a wooden fence beside the local Opera House. The credits, inscribed with chalk, stated: "Sychik + Khrushchik." The Fence Exhibition lasted just over three hours and was dismantled by police. The famoust Moscow so-called Bulldozer Exhibition took place seven years later-in September 1974. Many scholars consider these events as the official beginning of the USSR dissenting art.

In reality, everything started much earlier. Despite the fact that it is extremely difficult to establish the exact date of the beginning or end of the phenomenon or stylistic experiments when it comes to artistic processes, in the studies of Ukrainian nonconformism there is a date that according to the author's opinion should be regarded the official start of dissenting art. The author believes that the first nonconformists were the Kyiv-based monumental artists Ada Rybachuk and Volodymyr Melnychenko. They became the first official opponents to the state art authorities, thus setting the start to the second-stage Ukrainian artistic nonconformism:

I am talking about the notorious newspaper article "Art stands no hullabaloo," which was signed by the famous artists and workers of the Union of Artists of the Ukrainian SSR [4, p. 4].

Of course, many critical materials were issued prior to the mentioned one, still, this case was pioneering in systematic ruining of students' future careers by their teachers for not supporting the principles of socialist realism. After the intership on Kolguyev island, within the Arctic circle, the young artists in their creative works depicted the themes from real life that were not consistent with the principles of the official method. ARVM revealed the truth about the terrible life of people of the North, which was prohibited under the rules. It did not take long for the punitive apparatus to react. The article was signed by Vasyl Kasiyan and Mykhailo Deregus, the famous Soviet artists, both professors. Vasyl Kasiyan was a teacher of ARVM (abbreviation for Ada Rybachuk and Volodymyr Melnychenko) in the Kyiv State Art Institute.

The author considers this fact to be the first official act of dissent because on all previous similar occasions the articles critisizing artists or writers had a dead end. None of the accused managed to give an answer to accusations. People were afraid to engage into the struggle with the authorities. In this case, however, the story had a development. ARVM did issue an answer. Thus, the positional warfare between the artists and the leaders of the Union of Artists of Ukrainian SSR-Mykhailo Deregus and Vasyl Kasiyanunfolded. The study of the history of nonconformist art during its second stage in Ukraine gives grounds to link this phenomenon with modernism. It is reasonable to consider the Ukrainian nonconformist art of the 1960s-1980s period as a resumption of avant-garde tradition, interrupted by the official ideology of socialist realism. The early 1960s in the European countries were the time of worsening problems between the authorities and the new or revived old subcultures that logically turned into the counterculture, emphasizing the conflict of generations and the eternal irreconcilability of mass and elite art. In the case of the USSR and Ukrainian SSR, the conservatism of a totalitarian society, elevated to the rank of public morality, spawned nonconformists' counterculture. "An alternative model of existence," according to Achille Bonito Olivia's successful definition, finally began to be perceived by different artistic strata. The first ones to realize and fulfill this were the young artists. While the mid-1950s and early 1960s in European countries are marked with the process of rapid engagement of artists into abstract art, expressionist pop art, the 1960s and 1970s generate a large number of new artistic trends: from "new realism", kinetic art, mail art, minimalism, to "poor art", land art, hyperrealism, and body art. In Ukraine, out of all the mentioned trends, only hyperrealism was adopted. The era of postmodernism started globally, yet it had little effect on Ukrainian artists. The vast majority of Ukrainian artists continued to work according to the canon of socialist realism and to glorify the fictional hero in a non-existent historical plane. Of course, for money. The resistance of Ukrainian artists did not cross the country's borders. The political component even of the ideologically akin countries of the socialist camp differed from the Ukrainian one, and the demonstrations of disobedience by the artists of the German Democratic Republic, Poland, Czechoslovakia, Hungary were not identical to the manifestations of disobedience by Ukrainian artists.

Ukrainian nonconformist art was asserted as the creativity of individuals, regardless of the region of their residence. The region was less important. The process of artistic disobedience started in a city or town

\footnotetext{
-The author considers the first stage of Ukrainian nonconformism to be the struggle of the Mikhail Boychuk fellow artists against the official doctrine and apparatus during the 1930s.
} 
from an individual artist. There were two options of further development. The artist would either remain nonconforming and exposed himself to unemployment upon having no state commissions, to oblivion and constant attention of special services or the artist could undergo a serious pressure, intimidation and was subsequently "crushed", damping his desire to dissent. The vast majority of nonconformists were residents of Kyiv, Lviv, and Odessa. Nevertheless, there were artists from Cherkasy, Poltava, Dnipropetrovsk, Chernihiv, and Sumy. There also are recorded cases of artistic disobedience of workers of the art enterprises of Opishnia, Poltava, Korosten.

It seems obvious that the fate of nonconformism in such a specific society as the Soviet one was set in advance. However, something happened that could not have been foreseen by the "art historians" that in fact were the plain-clothed KGB agents. First silent and then public demonstrations of disobedience launched within the creative unions of artists, writers, workers of theater. Having all the understanding of the grim situation, the activists nevertheless did not stop, facing the possibility of oppression, of not receiving official earnings and even the worst case scenario of imprisonment.

The following cultural figures, true innovators and fighters, pleaded for individual non-socialist realistic creativity and for conscious standpoint in the Ukrainian second-stage nonconformism: Kyiv-Anatoliy Sumar, Valeriy Lamakh, Hryhoriy Havrylenko, Anatoliy Lymarev, Akim Levich, Ivan Marchuk, Feodosiy Humenyuk, Oleksandr Dubovyk, Alla Gorska, Ada Rybachuk, Volodymyr Melnychenko, Anatol Navrotsky; Lviv—Roman Selsky and Karlo Zvirynsky with their disciples; "informal academy" of Fedir Manailo in Uzhgorod, Volodymyr Makarenko (Dnipropetrovsk), Andriy Antonyuk (Mykolaiv); Odesa-Vladimir Strelnikov, Liudmyla Yastreb, Oleksandr Anufriyev, Victor Marinyuk, Valentin Khrushch.

The process of origination of the dissenting art of the 1950s and 1960s in the Ukrainian SSR was not identical to the ones in the other Soviet republics and countries of the Eastern Bloc. Ukrainian second-stage nonconformist art is a unique manifestation of national consciousness in an uneven struggle between the artist and dominant totalitarian regime.

\section{תimepamypa}

1.Авраменко О. Після соцреалізму // Нова генерація. Спецвипуск. 1992. С. 32-34.

2.Bown M. Socialists Realist Painting. London, 1998. 506 p.

3.Запис розмови з В. Микитою (2004). Київ: Фонд О. Роготченка. Касета 3.

4.Касиян В., Дерегус М. Искусство не терпит шумихи // Правда Украины. 1959. 27 сент.

5.Смирна Л. Століття нонконформізму в українському візуальному мистецтві. Київ: Фенікс, 2018. 478 с.

6.Сидоренко В. Д. Візуальне мистецтво від авангардних зрушень до новітніх спрямувань. Розвиток візуального мистецтва України XX-XXI століть. Київ: ВХ студіо, 2008. 188 с.

7.Синявский А. Что такое социалистический реализм? URL: https://imwerden.de/pdf/abram_terz_chto_takoe_ soc_realizm.pdf (дата обращения: 10.04.2019).

8.Федорук О. К. Перетин знаку: Вибр. мистецтвознавчі статті: У 3 кн. Київ : Інтертехнологія, 2008. Кн. 3: Українська культурологія. Історія та теорія мистецтва. Постаті. Народна творчість. Рецензії. 416 с.

\section{References}

1. Avramenko O. (1992). After socialist realism. Nova gheneracija, special issue, $32-34$ [in Ukrainian].

2. Bown M. (1998) Socialists Realist Painting. London.

3. Dereghus M, Kasijan V., (1959). Art does not endure the hype. Pravda Ukrajiny, p.4, 27/09, [in Ukrainian].

4. Zapys rozmovy z V. Mykytoju (2004). Kyjiv. Fond O. Roghotchenko. Kaseta 3, [in Ukrainian].

5. Smyrna L. (2018) Century of non-conformism in Ukrainian visual arts. Kyiv: «Vydavnyctvo «Feniks», [in Ukrainian].

6. Sydorenko V. D. (2008) Visual art from avant-garde shifts to the latest trends. Development of visual art of Ukraine of the XXXXI centuries. Kyiv: VKh studio, [in Ukrainian].

7. Synjavsjkyj A. (2005). What http://antology.igrunov.ru/authors/synyavsky/1059651903.html [in Russian] Realism? Retrieved from

8. Fedoruk O. K. (2008) Crossing sign. Vol 3. Kyiv: Intertekhnologhija, [in Ukrainian]. 